\title{
CHARACTERIZATION OF ULTRATHIN DIAMOND-LIKE CARBON FILMS
}

\author{
B. Tomčik \\ Institute of Physics, Center for Atomic and Subatomic Physics, Laboratory for \\ Atomic Collision Processes, Pregrevica 118, P.O. Box 68, Serbia
}

\begin{abstract}
Nano sized diamond-like carbon (DLC) films doped with nitrogen and hydrogen are materials of choice as a mechanical and corrosion protection barrier for magnetic layer of the computer hard disks. Overall thickness of a-C:N/a-C:H layer is bellow 2 $\mathrm{nm}$ and is usually accompanied by $0.5 \mathrm{~nm}$ thin flash layer of $\mathrm{Cr}$. To obtain dense and voidfree DLC films, different plasma and ion beam sources operated with hydrocarbon gases are now replacing sputtering deposition techniques. For the film characterization, mainly used are non-destructive optical techniques like micro-Raman spectroscopy and optical surface analysis. Various electrochemical and business environmental tests are common for the corrosion protection evaluation. Capabilities of the Rutherford back-scattering spectroscopy have been demonstrated in revealing the cobalt migration from the magnetic layer. Incorporation of the tribology layer into the magnetic layer, either oxide, carbide or nitridebased, and improvement of the lubricant properties, are the main developmental area in the modern hard disk drive structures.
\end{abstract}

Keywords: Diamondlike carbon, nanohardness, corrosion protection, micro-Raman.

\section{INTRODUCTION}

For the last 30 years, the sputtering technique was the dominant method for carbon film deposition from the solid carbon target in thicknesses above 4 $\mathrm{nm}$. Mostly used gas was argon mixed with reactive components like $\mathrm{H}_{2}, \mathrm{~N}_{2}$ and/or hydrocarbons. With further requirement for the increase of the area recording density, there was a need to reduce the carbon film thickness and, at the same time, provide voidfree, dense, corrosion protective, self-healing structure with good and controlled bonding with topping lubricant layer[1-3]. In spite of various process improvements, like introduction of the substrate low frequency bias technique, switch from large line-in planar magnetrons to single chamber operation units with changeable magnetron magnetic field patterns and introduction of carbon bi-layers (a-C:N on top of a-C:H film), it was not possible to deposit a good corrosion protective carbon films with thickness below $2 \mathrm{~nm}$. Also, there was a problem with film characterization. For carbon film thicknesses below 4 $\mathrm{nm}$ the signal-to-noise ratio in micro Raman spectroscopy was extremely low. This imposed long acquisition -signal accumulation times with possible ongoing change of the carbon film upon laser irradiation. Simple corrosion business environmental tests are the most effective in the evaluation of the film corrosion protection. By counting the number of corrosion spots per unit area, from the outer to inner diameter of the disk, it was possible to get the insight into the carbon film thickness uniformity. Due to the disk edge effects and non-continuity of the electric field across the disk surface, we could expect differences in carbon film thickness. Modern carbon deposition systems use mainly Kaufman DC ion beam or RF plasma beam sources (plasma CVD gun $^{\mathrm{TM}}$ ) in a dedicated single chamber deposition tool. Plasma diagnostics usually relies on the Faraday cup measurement of the ion beam current density and ion beam energy. Selected disks with carbon film on them are routinely inspected with the optical surface analysis tools. Aside from disk non-destructive inspection techniques for the failure analysis, the standard techniques, like Auger and X-ray photoelectron spectroscopy, SIMS, AFM and SEM, n\&k analyzer or FTIR spectroscopy, are useful in the film characterization. For the study of the corrosion products-migrated cobalt compounds from the magnetic layer, there are dedicated tools like inductively coupled plasma mass spectrometry of the collected material from the disk surface. In this work, the trace analysis of the migrated cobalt has been studied by using the Rutherford backscattering spectroscopy 
(RBS) while carbon film alone has been characterized with micro Raman spectroscopy. Surface defects were revealed by means of optical microscopy, AFM, TOFSIMS and optical surface analyzer.

\section{MICRO-RAMAN ANALYSIS OF ta-C FILM}

Argon ion laser at wavelength $514.5 \mathrm{~nm}$ and input power of $20 \mathrm{~mW}$ (Renishaw 2000) has been used in excitation of the glass/Ti $(10 \mathrm{~nm}) /$ $\mathrm{Co}_{66} \mathrm{Cr}_{22} \mathrm{Pt}_{12}(40 \mathrm{~nm}) / \mathrm{ta}-\mathrm{C}(5 \mathrm{~nm})$ structure. It was not possible to discern the characteristic carbon band structure (with D and $\mathrm{G}$ bands) due to small cross section for the Raman inellastic scattering on the $s p 3$ carbon and small film thickness, Fig.1. The expected carbon band contributions were: D -band at $\sim 1350$ $\mathrm{cm}^{-1}$ and G-band at $\sim 1580 \mathrm{~cm}^{-1}$.

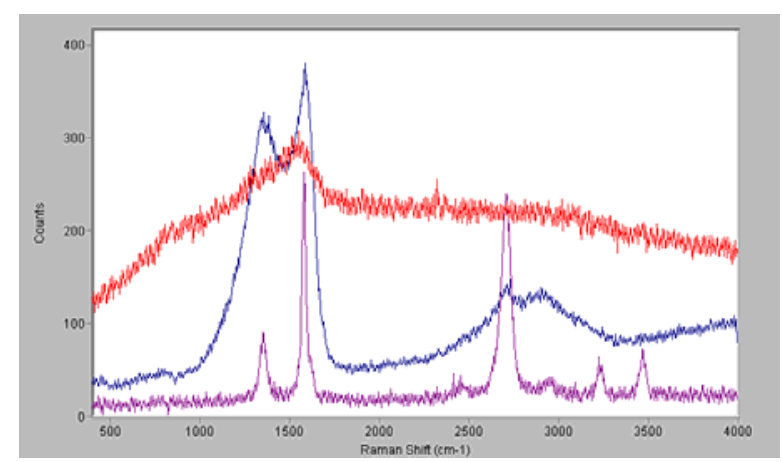

Figure. 1. Reference spectrum from the polycrystalline graphite target before erosion in the arc discharge

(lowest curve), after discharge exposure (middle curve) and of amorphous ta-C film deposited in the filtered cathodic arc, in the vawenumber region $400-4000 \mathrm{~cm}^{-1}$. The peaks of the graphite long-range crystal structure are: $1582 \mathrm{~cm}^{-1}$ (G-line) and $\sim 1355 \mathrm{~cm}^{-1} D$-line. The peaks above the $2000 \mathrm{~cm}^{-1}$ can be ascribed to the second order spectrum.

Even with optimized laser input power there was a difficulty in revealing the carbon band on the predominantly $s p^{3}$ ultra thin carbon film. It is well known that UV light irradiation can enhance the signal from the carbon phonon lattice in the $\mathrm{sp}^{3}$ coordination[3-6]. The tetrahedral carbon bonding in the film, deposited by filtered cathodic arc technique, is the dominant type of bonding. In the sputter deposited carbon films, the carbon band can be recorded more efficiently, due to larger cross section for laser inelastic scattering on $s p^{2}$ carbon structure, even for such small film thickness of only $5 \mathrm{~nm}$.

Conversion of the target polycrystalline graphite surface structure into an amorphous structure is due to the local overheating in the arc discharge and chemical reactions of the carbon with hydrogen and oxygen - the vacuum chamber residual gases.

\subsection{Raman analysis of ta-c films deposited with different substrate bias conditions}

In order to investigate at which substrate bias condition a ta-C film can possess the highest amount of $\mathrm{sp}^{3} / \mathrm{sp}^{2}$ coordinated carbon atoms, the experiments have been conducted by varying only the negative DC bias potential applied on the substrate. Instead of a more favorable UV Raman analysis, the visible micro-Raman study of as deposited films has been used. Since the Raman $\mathrm{I}_{\mathrm{D}} / \mathrm{I}_{\mathrm{G}}$ ratio is dependent on the incident laser power and the film deposition rate, a care has been taken in keeping all other deposition and testing conditions the same.

All ta-C films have been deposited under following conditions: deposition pressure $\sim 2.9 \times 10^{-6} \mathrm{~T}-$ orr, deposition time $5 \mathrm{~min}, \mathrm{X}$ and $\mathrm{Y}$ raster coil amplitude $1 \mathrm{~A}, \mathrm{X}$ and $\mathrm{Y}$ offset current amplitude $-4 \mathrm{~A}$ and $-1.5 \mathrm{~A}$, respectively. On the substrate holder, it was applied a negative DC voltage during a film deposition. After fitting the main carbon peak with two Gaussian peaks in the wave-number region 1000-2000 $\mathrm{cm}^{-1}$, all obtained results are given in Table 1 .

Table 1. Fitting results obtained from Raman spectra in the wave-number region $1000-2000 \mathrm{~cm}^{-1}$.

\begin{tabular}{|l|l|l|l|l|}
\hline $\begin{array}{l}\text { Substrate } \\
\text { bias }(\mathrm{V})\end{array}$ & $\begin{array}{l}\mathrm{G} \text { band } \\
\left(\mathrm{cm}^{-1}\right)\end{array}$ & $\begin{array}{l}\mathrm{D} \text { band } \\
\left(\mathrm{cm}^{-1}\right)\end{array}$ & $\mathrm{I}_{\mathrm{D}} / \mathrm{I}_{\mathrm{G}}$ & Slope $(\mathrm{cm})$ \\
\hline 0 & 1567.8 & 1438.5 & 1.71 & 0.024 \\
\hline-25 & 1566.6 & 1369.2 & 0.39 & 0.118 \\
\hline-50 & 1565.3 & 1356.9 & 0.28 & 0.098 \\
\hline-75 & 1571.0 & 1388.5 & 0.59 & 0.057 \\
\hline-150 & 1570.3 & 1455.1 & 2.17 & 0.035 \\
\hline-200 & 1576.4 & 1461.8 & 2.39 & 0.122 \\
\hline
\end{tabular}

Some of micro-Raman spectra, used for the above analysis, are shown in the Fig.2.

The values of $I_{D} / I_{G}$ ratio as well as the D-band Raman shift versus the substrate bias are separately depicted in Fig. 4.

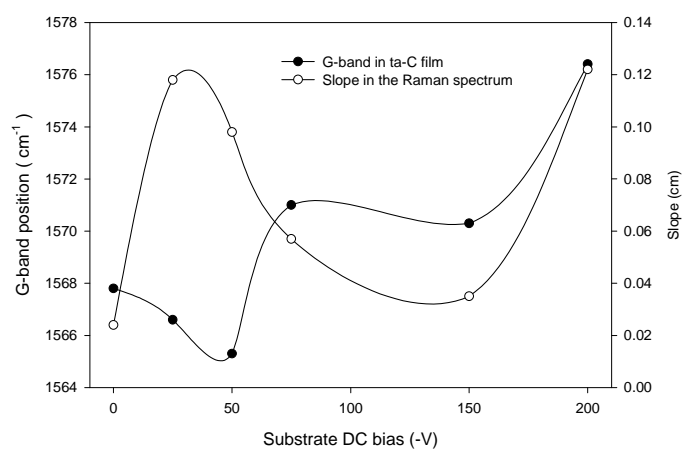

Figure 2. Raman analysis of ta-C films at different substrate bias potentials 


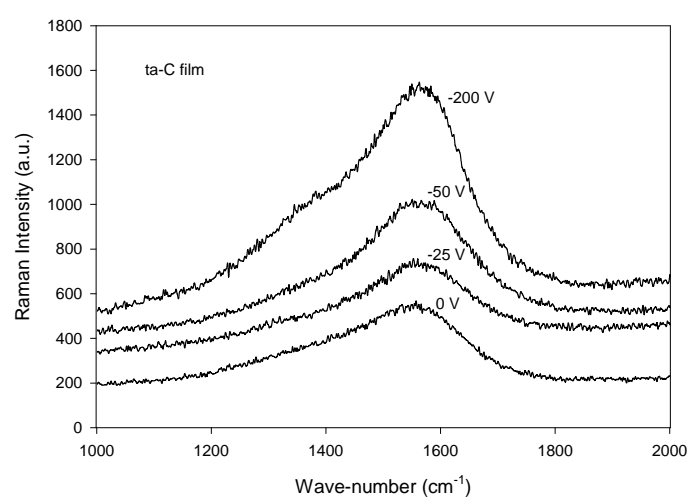

Figure 3. Dependence of the G-band shift and a slope of Raman spectrum with substrate bias for ta-C film in the fitted region 1000-2000 $\mathrm{cm}^{-1}$

Along with the natural acquired energy of positively ejected carbon ions of $\sim 28 \mathrm{eV}$, leaving the plasma sheath in the vicinity of graphite target, an additional energy acquired close to the substrate of $50 \mathrm{eV}$ will result in the highest $\mathrm{sp}^{3}$ tetrahedral coordination of the carbon atoms. Therefore, without taking into account the film stress, friction coefficient or other film properties, the applied substrate bias of $\sim-50 \mathrm{~V}$ could lead to the highest degree of diamond-like film properties. At substrate bias of $50 \mathrm{~V}$ the G-band curve also passes through its $\mathrm{m}$ inimum in the low wave-number side, Fig.3. The 1inearly fitted slope dependence of the Raman spectra in the $1000-2000 \mathrm{~cm}^{-1}$ range versus substrate bias (photoluminescence) is correlated to the amount of hydrogen incorporated in the film. Since all experiments have been performed in the low pressure $r$ esidual gas, the hydrogen may only origin from the water vapor occluded in the chamber wall. This hydrogen content in ta-C films is usually less than 5 at. $\%$. The slope dependence versus applied negative bias passes through its distinctive maximum at $30 \mathrm{~V}$.

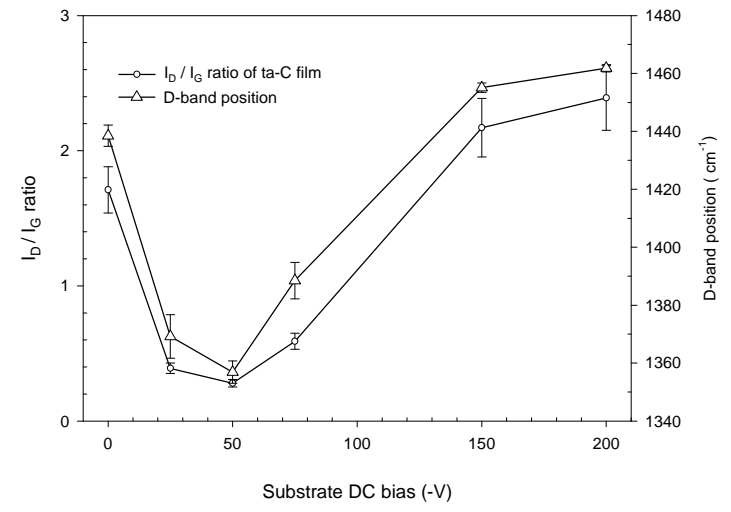

Figure 4. Dependence of the $I_{D} / I_{G}$ ratio and the D-band position with the substrate bias. Raman spectra were acquired at $10 \mathrm{~mW}$ laser power, $514.5 \mathrm{~nm}$.
The higher positive shift of $\mathrm{D}$ band with increasing the substrate bias over $50 \mathrm{~V}$ means a development of more $\mathrm{C}=\mathrm{C}, s p^{2}$ bonds between carbon atoms.

\subsection{Raman analysis of the multilayered} $\mathrm{CrC} / \mathrm{C}$ and $\mathrm{BC} / \mathrm{C}$ film

Nano-lamination of carbon films with compounds that can form carbide structure with constituent elements in the magnetic layer (here with $\mathrm{Cr}$ and $\mathrm{B}$ ) is one of the approaches for obtaining additional overcoat mechanical strength against potential $\mathrm{read} /$ write head impact. Such multilayered structure has been examined with respect to the overall nanohardness, Young modulus of elasticity and film corrosion protection $[7,8]$. In this paper there are presented respective micro-Raman spectra of these multilayered structures, $\mathrm{CrC} / \mathrm{C}$ and $\mathrm{BC} / \mathrm{C}$ in Fig. 5 and Fig. 6, respectively.

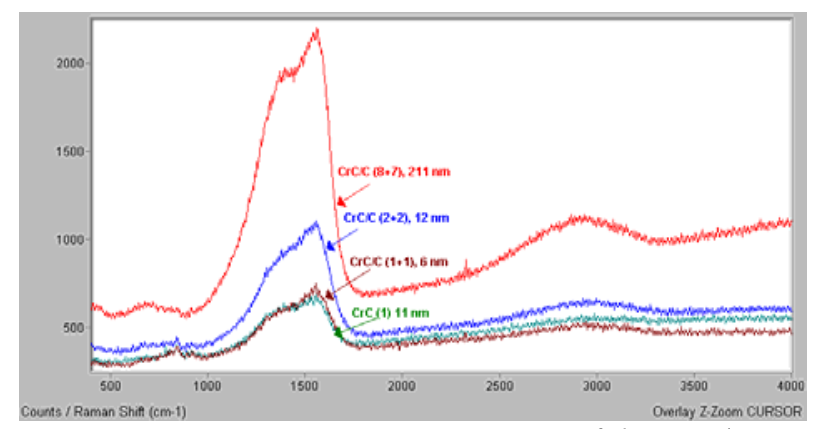

Figure 5. Overview Raman spectra of the $\mathrm{CrC} C \mathrm{C}$ multilayered films deposited over magnetic layer of a hard disk.

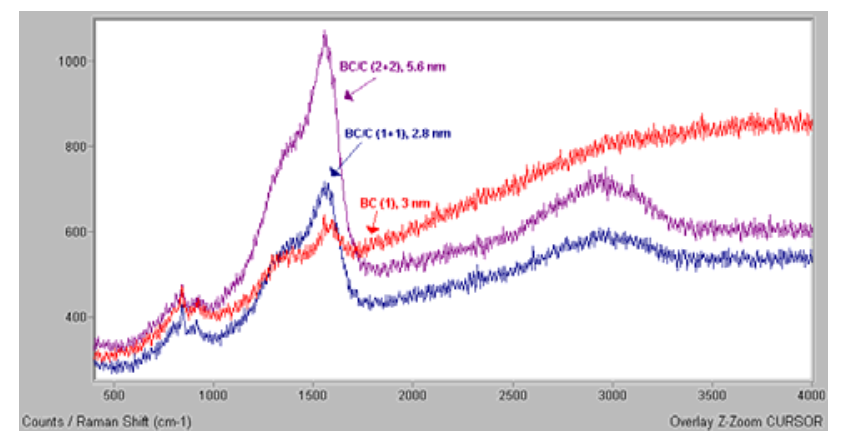

Figure 6. Overview of the Raman spectra of the multilayered $B C / C$ film deposited on the magnetic layer of a hard disk. Inset: Deconvolution of the main carbon peak by two Gaussian peaks on the $2.8 \mathrm{~nm}$ thin $\mathrm{BC} / \mathrm{C}$ film. In the fitting region $1000-1900 \mathrm{~cm}^{-1}$ it is possible to see shoulder in the carbon D-peak

Area under the main carbon peak is proportional to the film thickness-carbon content in a film. Fitting of the main carbon peak of the $\mathrm{CrC} / \mathrm{C} 6 \mathrm{~nm}$ thin film took place by means of two Gaussian cur- 
ves. Maximum of D-peak is at $1402 \mathrm{~cm}^{-1}$ and of Gpeak at $1568 \mathrm{~cm}^{-1}$.

Table 2. Fitting parameters of the $G$ and D-peak for the $\mathrm{CrC} / \mathrm{C}$ multilayer film.

\begin{tabular}{|l|l|l|l|}
\hline $\begin{array}{l}\text { Film / layer / } \\
\text { thickness }(\mathrm{nm})\end{array}$ & $\mathrm{I}_{\mathrm{D}}\left(\mathrm{cm}^{-1}\right)$ & $\mathrm{I}_{\mathrm{G}}\left(\mathrm{cm}^{-1}\right)$ & $\mathrm{I}_{\mathrm{D}} / \mathrm{I}_{\mathrm{G}}$ \\
\hline $\mathrm{CrC} / \mathrm{C}(1+1), 6$ & 1402.3 & 1568.4 & 2.45 \\
\hline $\mathrm{CrC} / \mathrm{C}(2+2), 12$ & 1405.9 & 1566.6 & 2.97 \\
\hline $\begin{array}{l}\mathrm{CrC} / \mathrm{C}(8+7), \\
211\end{array}$ & 1397.9 & 1571.3 & 3.68 \\
\hline $\mathrm{CrC}$ bulk, 11 & 1388.3 & 1566.5 & 3.23 \\
\hline
\end{tabular}

Table 3. Fitting parameters of the $G$ and D-peak for the $B C / C$ multilayer film.

\begin{tabular}{|l|l|l|l|}
\hline $\begin{array}{l}\text { Film / layer / } \\
\text { thickness }(\mathrm{nm})\end{array}$ & $\mathrm{I}_{\mathrm{D}}\left(\mathrm{cm}^{-1}\right)$ & $\mathrm{I}_{\mathrm{G}}\left(\mathrm{cm}^{-1}\right)$ & $\mathrm{I}_{\mathrm{D}} / \mathrm{I}_{\mathrm{G}}$ \\
\hline $\mathrm{BC} / \mathrm{C}(1+1), 2.8$ & 1388.8 & 1571.7 & 1.77 \\
\hline $\mathrm{BC} / \mathrm{C}(2+2), 5.6$ & 1409.6 & 1569.9 & 2.47 \\
\hline $\mathrm{BC}$ bulk, 3 & 1355.3 & 1576.9 & 1.46 \\
\hline
\end{tabular}

Common features that can be deducted from both $\mathrm{CrC} / \mathrm{C}$ and $\mathrm{BC} / \mathrm{C}$ multilayer $\mathrm{D}$ and $\mathrm{G}$ peak parameters, as presented in the Table 2 and Table 3 , are:

- With increase of the multilayers number in the film, the area intensity ratio $I_{D} / I_{G}$ shows a constant increase.

- The $\mathrm{I}_{\mathrm{G}}$ value passes through minimum with increase of the multilayers number for $\mathrm{CrC} / \mathrm{C}$ film. A decrease is also observed for the $\mathrm{BC} / \mathrm{C}$ film $\mathrm{G}$-line intensity with increase of bi-layers from one to two.

- The $\mathrm{I}_{D}$ value passes through maximum with increase of the multilayers number for $\mathrm{CrC} / \mathrm{C}$ film. An increase is also observed for the $\mathrm{BC} / \mathrm{C}$ film D-line intensity with increase of bi-layers from one to two.

The above wavelength dependence of the $G$ and D-peaks can be used for the multilayer film characterization. For example, in: a) establishing a laboratory standard for the measurements of the multilayers number in a film b) determination of the carbon as a film forming layer and c) for the film thickness measurement.

\section{FILM COMPOSITION STUDY OF ta-C AND ta-C:N FILM}

Film composition has been evaluated by TOF SIMS (Time of flight secondary ion mass spectrometry) by using commercially available instrument $\mathrm{C}$ AMECA, TOF-SIMS IV (ION-TOF GmbH). Ejected positive ions have been obtained by using Gall- ium gun at $25 \mathrm{keV}$ and a current of $2.4 \mathrm{pA}$. For the film sputtering an Argon gun at $3 \mathrm{keV}$ and $35 \mathrm{nA} \mathrm{cu}-$ rrent have been used. Usually, the film analysis area was $100 \times 100 \mu \mathrm{m}$ within the sputtered area 200x200 $\mu \mathrm{m}$. Typical depth profile analysis and surface image spectrum is shown in the Fig.6 and Fig.7, respectively. Since a film deposition took place at very low pressure, in the $10^{-6}$ Torr range, only a small amount of oxygen at the interface was present. The presence of silicon at the top of the film comes from the Si dust, created after the film deposition, during cutting the sample - preparation for the film analysis.

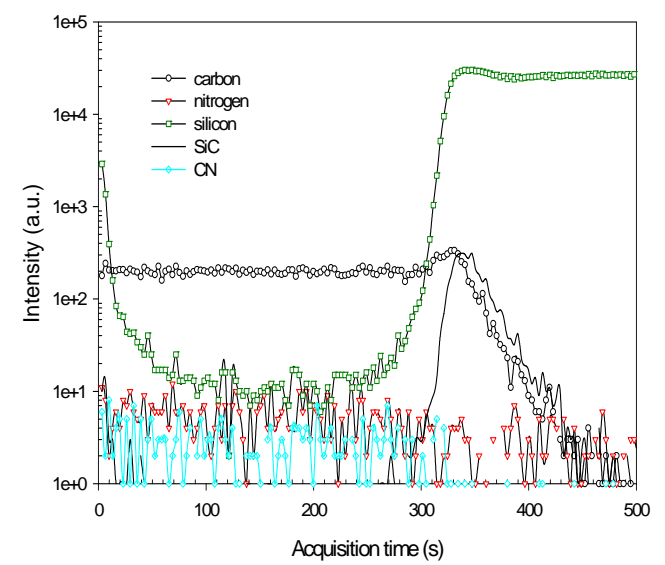

Figure 7. TOF SIMS depth profile analysis of ta-C/Si wafer film with characteristic element distribution.

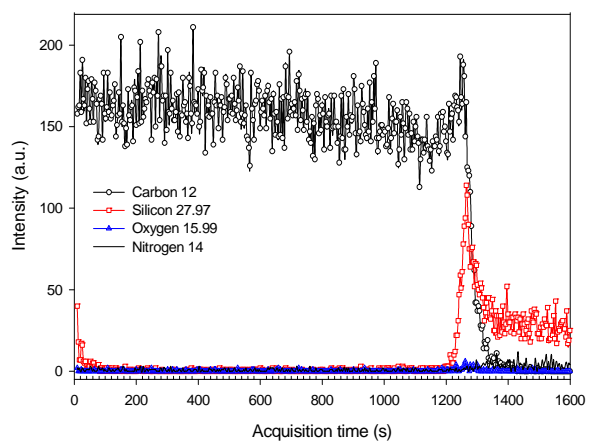

Figure 8. Depth profile analysis of the ta-C:N sample by TOF SIMS.

Positive ions of $\mathrm{SiC}$ are created at the film $/ \mathrm{Si}$ substrate interface. Also a decrease of the $\mathrm{CN}$ ion signal can be observed at the interface. From the FWHM of the SiC signal in the linear scale presentation, we can conclude that the $\mathrm{SiC}$ interface width is $\sim 2.7 \mathrm{~nm}$. In order to increase the signal from the positive ions, an oxygen leak has been established, up to the main chamber pressure of $5 \times 10^{-6}$ mbar.

Not shown, but also present in the overall spectrum, are the contributions from the $\mathrm{Na}$ and $\mathrm{K}$ ions, developed only on the interface and the film 
surface. Their presence originates from improperly cleaned Si substrate, before the film deposition, and from keeping the film in a plastic container. Beside $\mathrm{Na}$ and $\mathrm{K}$, other abundant positive ions were: $\mathrm{SiHO}$, $\mathrm{CHO}, \mathrm{CO}, \mathrm{CH}_{3}, \mathrm{NH}_{4}, \mathrm{C}_{2} \mathrm{H}, \mathrm{C}_{2} \mathrm{H}_{3}$ and $\mathrm{CH}_{2} \mathrm{~N}$. Among the most dominant peaks there are $\mathrm{Ar}$ and $\mathrm{Ga}$, used for sputter etching and film analysis. Oxygen in structure of positive ions comes from the substrate flooding-during film analysis. In the depth profile spectra, it was possible to see the contribution from the $\mathrm{Cr}$ and $\mathrm{Fe}$ signal - probably coming from the stainless steel target holder in the FCA facility.

\section{RBS STUDY OF CARBON/DISK STRUCTURE}

With RBS spectroscopy it is possible to examine and quantify the elemental depth composition of magnetic layer, flash layer and carbon overcoat. Also, this technique could be used in the study of corrosion products, mainly migrated cobalt and its compounds on the disk surface. The area that could be analyzed is up to $1 \mathrm{~mm}$ in diameter. This technique could provide the point values of e.g. surface concentration of corrosion products on the carbon surface. Measured surface concentration of Co can be further related to the carbon film density, carbon porosity and coverage uniformity across the disk.

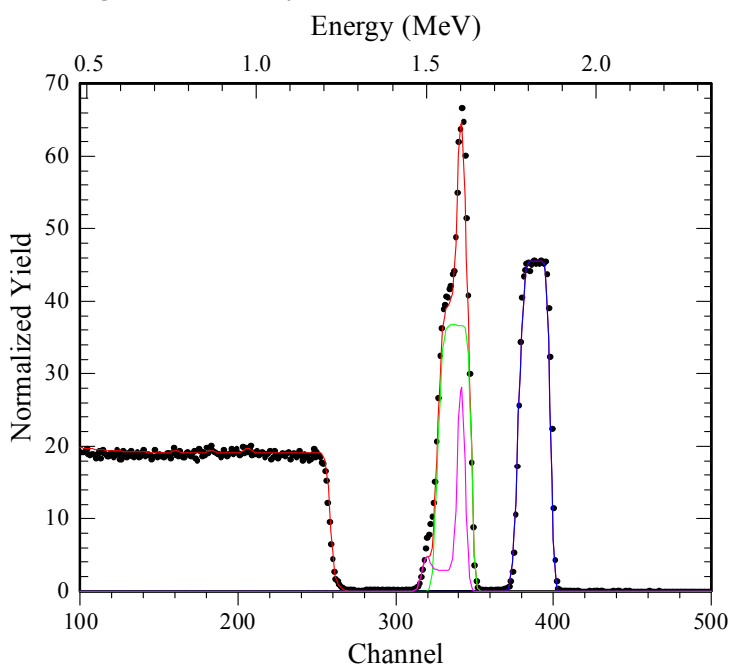

Figure 9. Reference spectrum of the CoCr Pt magnetic layer. FWHM of Co peak $\sim 0.106 \mathrm{MeV}$

The incident ion with energy $E_{0}$ first suffers the energy loss on the migrated Co on the top on the surface and, additionally, on the return trip to detector, after having probed the magnetic layer with platinum content. Therefore, the broadening and energy position of the well resolved Pt peak can be used in evaluating the amount of cobalt on the top of the surface.
The total number of counts in the RBS spectrum is proportional to the integrated beam charge $I$, the acceptance angle of the Si detector $(\Delta \Omega)$, number of scattering centers per $\mathrm{cm}^{2}(N \Delta Z)$ and the differential cross section of the scattered species $(d \sigma / d \Omega$.) $[9,10]$.

The samples were exposed to the $0.5 \mathrm{M} \mathrm{HCl}$ corrosion vapor for up to 284 hours. Migrated Co on top of the carbon caused a change of the $G$ and $D$ peak shifts in the micro Raman spectrum, as well as the change in the FWHM of Co and Pt peak in RBS spectrum. The corrosion treated sample shows the smallest value in G-area. This is an indication of the carbon dissolution and ovelapping of its surface with migrated cobalt corrosion products.

There is an ongoing research on the interpretation of RBS spectra - which parameter or sets of parameters best describe the changes on the disk surface.

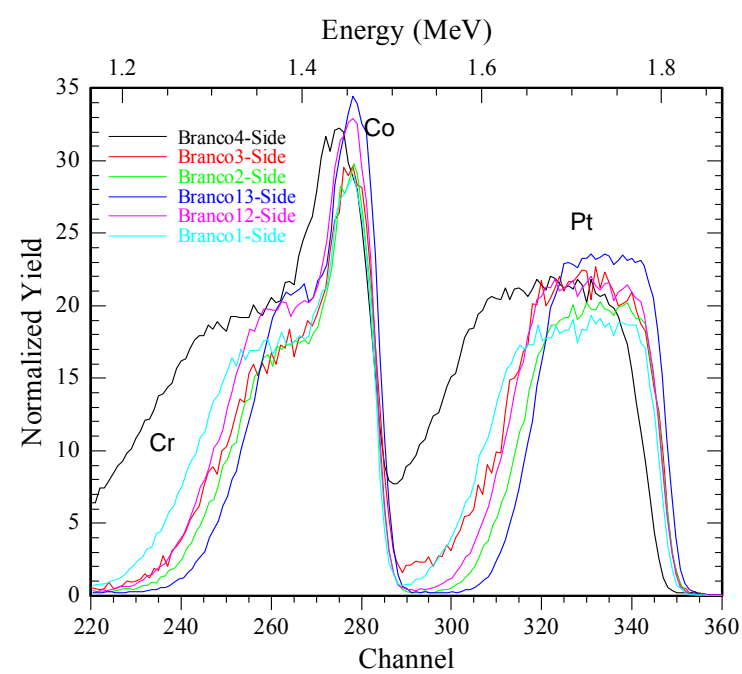

Figure 10. RBS spectra of the same sample exposed to different corrosion conditions and different RBS signal collecting methods(top and side arrangements).

The RBS method is a point sensitive acquisition tool that averages DLC properties within radius of $1 \mathrm{~mm}$. Therefore, the disk results may significantly differ, from point to point, on the disk surface.

\section{ACKNOWLEDGMENTS}

The author would like to thank Prof. Benninghoven, University of Mainz, for the results obtained on the TOFSIMS instrument, Prof. Osipowicz, National University of Singapore, for the RBS analysis and A*STAR, Singapore's Agency for Science, Technology and Research. 


\section{REFERENCES}

[1] A. C. Ferrari, J. C. Robertson, Phys. Rev. B61(2000)1409

[2] N. Ravi, V. I. Bukhovets, I. G. Varshavskaya, G. Sunfararajan, Diamond.Relat.Mater.16 (2007) 90

[3] W. Gou, G. Li, X. Chu, B. Zhong, Surf. Coat. Technol. 201(2007)5043

[4] J. J. Li, C. Z. Gu, H.Y. Peng, H. N. Wu, W. T. Zhong, C. Z Jin, Appl. Surf. Sci. 251(2005)236
[5] J. Robertson, Surf. Coat. Technol. 50(1992) 185

[6] J. Noshiro, S. Watanabe, T. Sakurai, S. Miyake, Surf. Coat. Technol. 200(2006)5849

[7] B. Balakrisnan, B. Tomcik, D.J. Blackwood, J. Electrochem. Soc. 149 (3) (2002) B84

[8] B.Tomcik, S. C. Seng, B. Balakrisnan, J. Y. Lee, Diamond and Rel. Mater, 11 (2002)1409

[9] W. K. Chu, J. W. Mayer and M. A. Nicolet, Backscattering Spectrometry, (1978), Academic Press, New York.

[10] L. R. Doolittle, Nucl. Instr. and Methods, B9, (1985), 344.

$\operatorname{son}$

КАРАКТЕРИЗАЦИЈА УЛТРАТАНКИХ ДИЈАМАНТУ СЛИЧНИХ УГЉЕНИЧНИХ ФИЛМОВА

Сажетак: Дијаманту сличне угљеничне превлаке нанометарске дебљине, допиране водоником и азотом, користе се као најбоља механичка и заштитна корозиона баријера на компјутерским чврстим дисковима. Укупна дебљина ових аморфних a-C:N/a-C:H структура је испод 2 нм и обично им претходи нанесени 0,5 нм танки слој хрома. Уместо досадашњих техника распршивања, за добијање густих и без отвора угљеничних филмова користе се углавном плазмени и јонски снопови од угљоводоничних гасова. За карактеризацију филмова су пожељне недеструктивне оптичке методе, попут микро-Рамана и оптичке површинске анализе. За процену корозионе заштите коришћени су различити електрохемијски и радни амбијентални тестови док је за откривање миграције кобалтових атома из магнетног слоја коришћена Rutherford-ова спектроскопија повратног расејања. Уградња триболошког слоја унутар магнетног слоја, било да је на оксидној, карбидној или нитридној основи, и побољшање особина лубриканта, главни су правци развоја код модерних структура компјутерских чврстих дискова.

Кључне речи: дијаманту сличан угљеник, нанотврдоћа, корозиона заштита, микро-Раман. 